\title{
Simulation of various DC-DC converters for photovoltaic system
}

\author{
R. Palanisamy, K. Vijayakumar, V. Venkatachalam, R. Mano Narayanan, \\ D. Saravanakumar, K. Saravanan \\ Department of Electrical and Electronics Engineering, SRM Institute of Science and Technology, Kattankulathur, \\ Chennai, India
}

\begin{tabular}{l} 
Article Info \\
\hline Article history: \\
Received Jun 7, 2018 \\
Revised Sep 26, 2018 \\
Accepted Oct 23, 2018 \\
\hline
\end{tabular}

\section{Keywords:}

Boost converter

Buck converter

Buck-boost converter

Cuk converter

Maximum power point tracking

(MPPT)

Photovoltaic (PV) system

Sepic converter and zeta

converter

\section{Corresponding Author:}

R. Palanisamy,

Department of Electrical and Electronics Engineering,

SRM Institute of Science and Technology,

Kattankulathur, Chennai, India.

Email: krspalani@gmail.com

\begin{abstract}
This work explains the comparison of various dc-dc converters for photovoltaic systems. In recent day insufficient energy and continues increasing in fuel cost, exploration on renewable energy system becomes more essential. For high and medium power applications, high input source from renewable systems like photovoltaic and wind energy system turn into difficult one, which leads to increase of cost for installation process. So the generated voltage from PV system is boosted with help various boost converter depends on the applications. Here the various converters are like boost converter, buck converter, buck-boost converter, cuk converter, sepic converter and zeta converter are analysed for photovoltaic system, which are verified using matlab / simulink.
\end{abstract}

Copyright () 2019 Institute of Advanced Engineering and Science. All rights reserved.

\section{INTRODUCTION}

The gigantic utilization of a natural fuel such as coal, oil sources and natural gases contaminates atmosphere and grades in sombre effect to environment of the world [1]. So to avoid the limitations of nonrenewable system like energy waste and environmental pollution, which leads to power generation using renewable systems like PV and wind energy system [2], [3]. Photovoltaic power contraption is a consistent and more inexpensive source of electricity in pastoral area network and acting a major role in the enlargement of disseminated electrical systems [4]. PV systems are solar energy supply systems, which moreover supply power directly to electrical applications or some storage systems like grid or battery scheme [5], [6].

Solar power energy can be employed in two main customs. Firstly the incarcerate high temperature can be worn as solar thermal power energy, with relevance's in space heating [7]. An additional substitute is the conversion of occurrence solar radiation to electrical energy, which is the mainly exploitable form of energy source [8]. This can be accomplished with facilitate of solar photovoltaic cells or with absorbed solar energy power plants. The grid connected PV system does not necessitate a battery because the grid can accumulate the power engendered by the PV array [9]. 


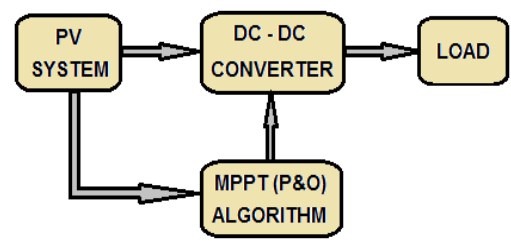

Figure 1. Block diagram of system outline

The switched dc-dc converters assist in escalating the voltage beginning a low battery voltage source thereby smooth the progress of in achieved a synchronized DC output voltage which would moderately necessitate numerous battery voltage sources [10]. Generally to improve the output of renewable energy system, the dc-dc converters employed. The relevance of dc-dc converters engross the following requirements like high step up output voltage gain, low input current and low current ripples, high output voltage and low voltage ripples and higher efficiency[11], [12]. The various dc-dc converters are design with help of conventional coupled inductor, switched capacitor, clamping diodes and controlled power semiconductor device, which is controlled by duty ratio. Based on duty ratio of dc-dc converter the output voltage can be increased or decreased. The block diagram of system outline is shown in Figure 1.

This paper gives idea about comparison of various dc-dc converters for photovoltaic systems, which are boost converter, buck converter, buck-boost converter, cuk converter, sepic converter and zeta converter are analysed with various duty ratio conditions. The system is verified using matlab / simulink tool.

\section{PV SYSTEM AND MPPT ALGORITHM}

\subsection{PV system modelling}

A photovoltaic (PV) cell unit or photoelectric cell unit is a power semiconductor device that exchanges light energy source to electrical energy source by PV effect condition [13]. If the energy source of photon of light is superior to the band gap afterwards the electron is released and the electron flow generates current source. Nevertheless a photovoltaic cell unit is dissimilar from a photodiode unit. In a photodiode unit light source falls on n-channel semiconductor junction point and obtain rehabilitated into current or voltage signal but a photovoltaic cell unit is forever forward biased condition [14]. PV array modelling circuit is shown in Figure 2.

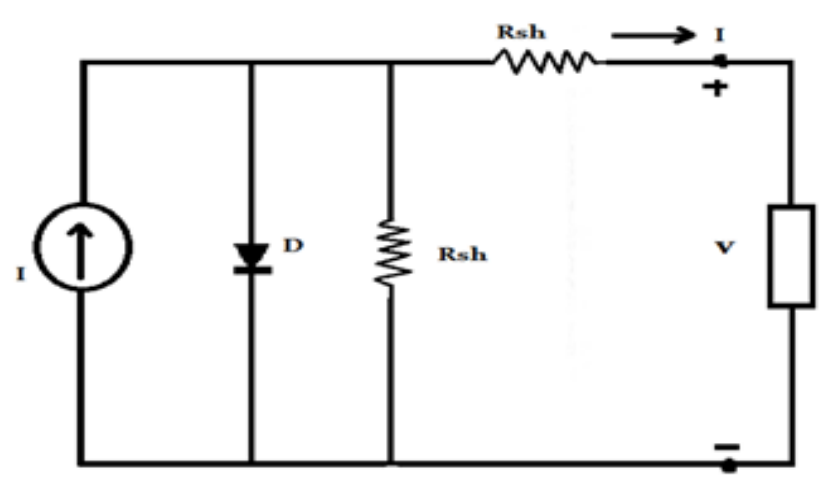

Figure 2. PV array modelling circuit

A PV array unit contains of numerous photovoltaic cells in series connections and parallel connections. Series connected schemes are accountable for escalating the voltage of the system while the parallel connected schemes are accountable for escalating the current in the system [15]. In generally a solar cell scheme can be designed by a current source and an upturned diode associated in parallel to system. It has its own series resistance and parallel resistance to improve the system voltage and current [16]. Series resistance is due to impediment in the path of electrons flow from n-channel semiconductor to p-channel semiconductor junction point and parallel resistance is due to the leakage current, the system 
output current from the photovoltaic array unit depends on,

$$
\begin{aligned}
& I=I_{s c g}-I_{d d} \\
& I_{d}=I_{p}\left(e^{y v_{d d}} / w Q\right.
\end{aligned}
$$

Where Ip is the reverse saturation current of the diode, $\mathrm{y}$ is the electron charge, Vdd is the voltage across the diode, w is Boltzmann constant and Q is the junction temperature, from Equations (1) and (2),

$$
\begin{aligned}
& I=I_{s c g}-I_{p}\left(e^{\frac{y v d d}{w Q}}-1\right) \\
& I=I_{s c g}-I_{p}\left(e^{q\left(\frac{V+I R_{s}}{n w Q}\right)}-1\right)
\end{aligned}
$$

In instruct to representation the solar panel unit, it necessitates two diode scheme models but in the projected performance, it is inadequate to the single diode model. Also, the shunt resistance is very elevated and can be deserted during the path of the discussion [13].

\subsection{MPPT algorithm (P\&O method)}

A distinctive solar panel unit exchanges only 30 to 40 percent of the incident light solar irradiation source into electrical energy source. To improve the efficiency of the PV system the Maximum power point tracking technique (MPPT) method is used. According to Maximum Power Transfer theorem, the power output of a circuit is improved, when system source impedance matches with the load impedance of the PV system. P-V system characteristics curve of photovoltaic cell unit and tracking of MPP value by P\&O method beneath quickly altering irradiance is shown in Figure 3.
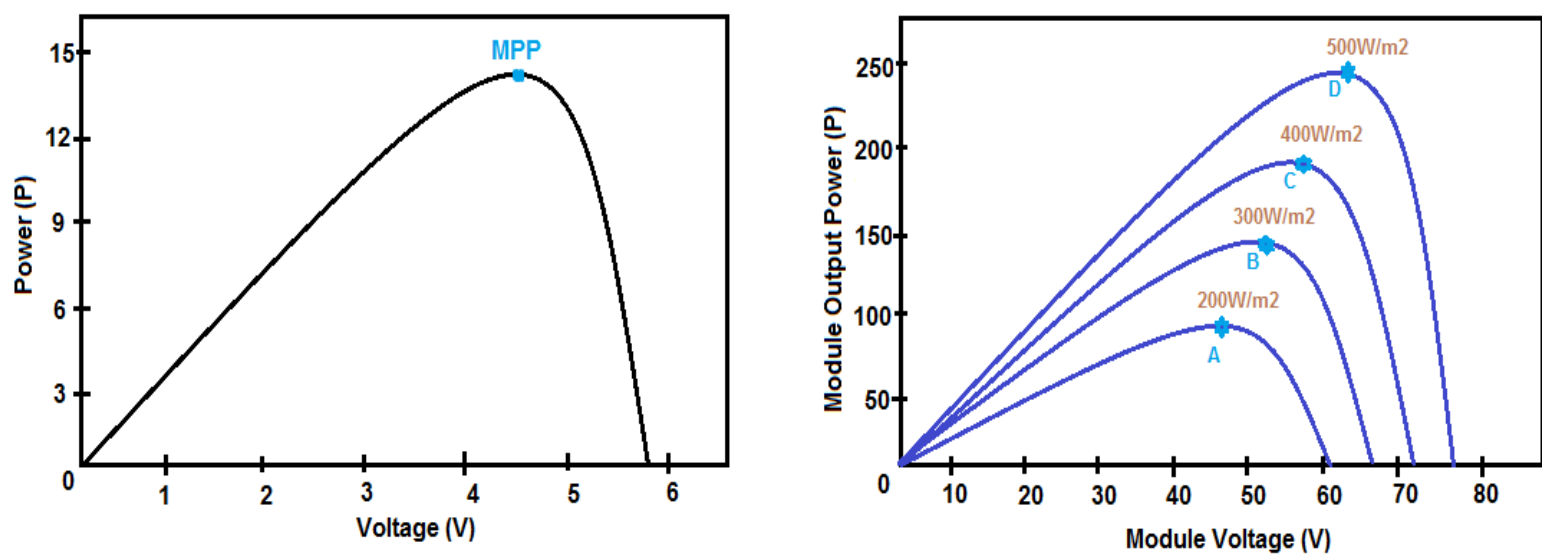

Figure 3. (a) P-V characteristics curve of photovoltaic cell (b) tracking of MPP by P\&O algorithm under rapidly varying irradiance

Perturb \& Observe $(\mathrm{P} \& \mathrm{O})$ is the one of MPPT method, which simple and easy to design. It employs only one voltage sensor unit, to sense the PV array voltage value and so the cost of accomplishment is very less and therefore uncomplicated to execute. The time intricacy of this MPPT algorithm is very minimum, but on attainment extremely secure to the reach MPP it doesn't discontinue at the MPP and maintain on disquieting on both the directions of the system.

The Perturb \& Observe MPPT scheme conditions that when the working voltage source of the PV panel unit is perturbed by a diminutive augmentation, if the ensuing revolutionize in change in power $\Delta \mathrm{P}$ is positive charge $(\Delta \mathrm{P}>0)$, then it transform to budge in the track of MPP and it remain on disquieting in the same direction of system. If $\Delta \mathrm{P}$ is negative charge $(\Delta \mathrm{P}<0)$, it leaves absent from the direction of MPP and the indication of perturbation abounding has to be distorted. The flowchart for $\mathrm{P} \& \mathrm{O}$ algorithm is shown in Figure 4. 


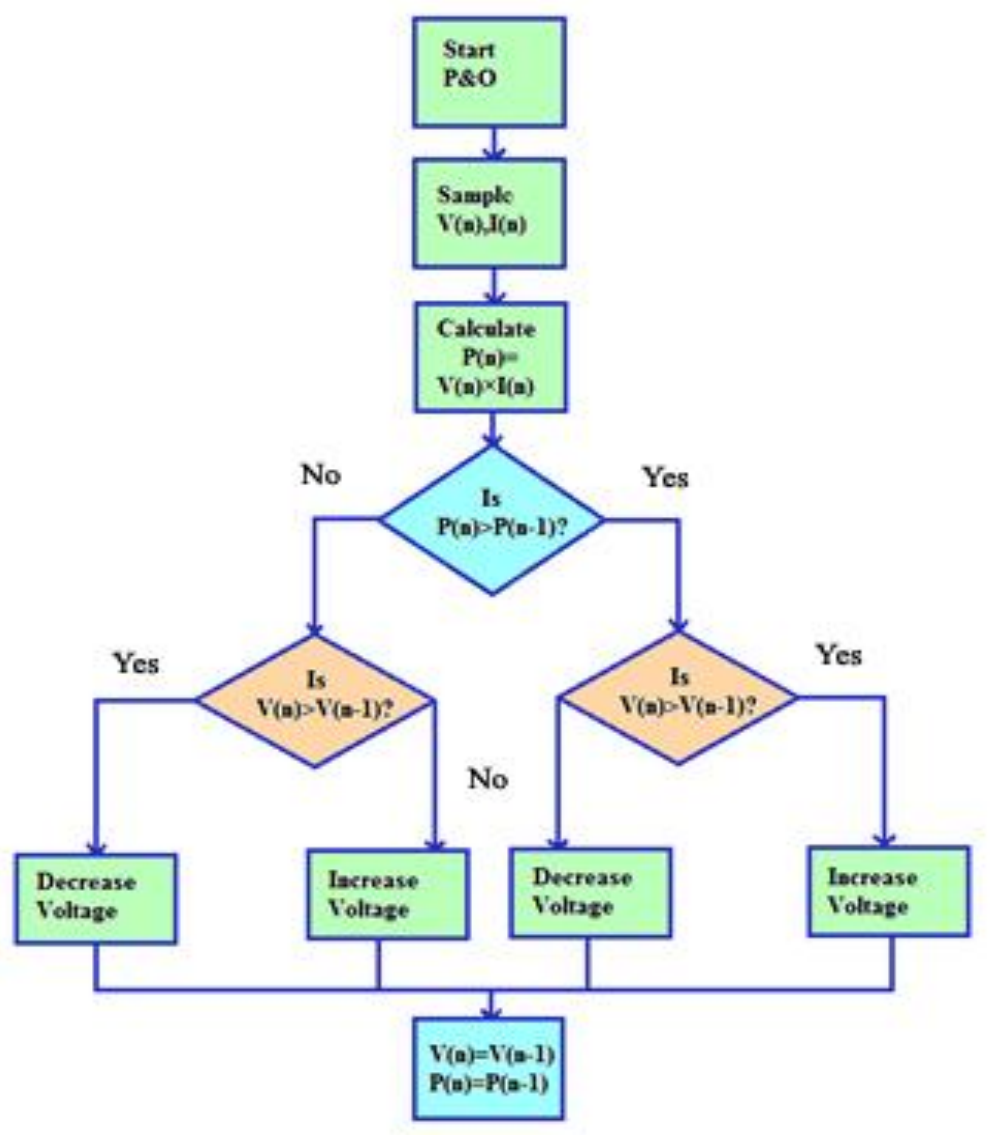

Figure 4. Flowchart for $\mathrm{P} \& \mathrm{O}$ algorithm

\section{COMPARISON OF VARIOUS DC-DC CONVERTERS}

The dc-dc converter is electronic system which converts dc source voltage from one voltage range to another voltage range. It attracts many researchers to boost or increases output voltage from the renewable energy systems like fuel cell, PV system and wind energy system. The conventional dc - dc converters are power switching converter which innately introduces a certain amount ripple in current output, which is minimised with help of advanced dc-dc converters like sepic converter and zeta converter. Generally the conventional dc-dc converters only applicable for low power applications, which are developed to high power applications using isolated and non isolated converters. In Figure 5 shows the diagram for boost converter, which is used to boost input dc voltage. When the power switch is ON condition, the inductor charge energy in the form of electromagnetic field and discharge energy when power switch is off condition. The time constant RC of the circuit depends on the capacitor size. The output voltage boost level depends on the duty ratio of the switch and applied input voltage, which is defined as,

$$
V_{0}=V_{i}(1-G)
$$

Where, Vo is output voltage, $\mathrm{Vi}$ - input voltage and G- duty ratio.

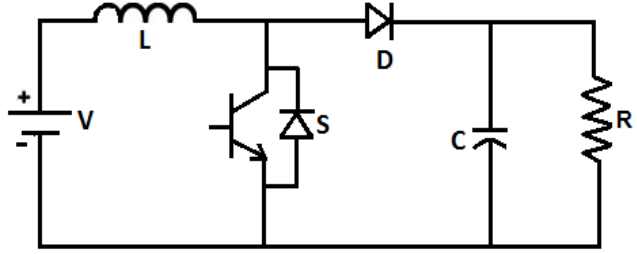

Figure 5. Circuit diagram of boost converter

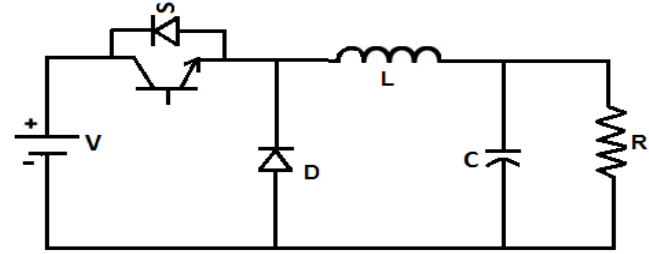

Figure 6. Circuit diagram of buck converter 
In Figure 6 shows the diagram of Buck converter, which is the output voltage is less than that of applied input voltage, here when the switch is ON condition, the current flows through inductor and capacitor. The switch brings to off condition the supply is disconnected from source, which leads minimise the voltage than source voltage. The output voltage equation is written as,

$$
V_{0}=V_{i} * G
$$

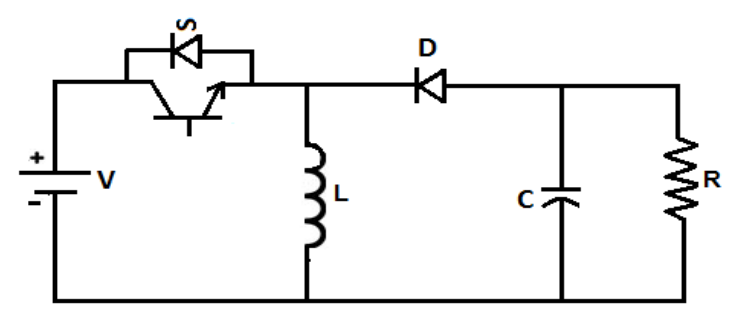

Figure 7. Circuit diagram of buck - boost converter

Similarly buck-boost converter used to do the both increase the voltage level and decrease the voltage level of applied input voltage. The output voltage equation can be defined as, Circuit diagram of buck - boost converter, which is shown in Figure 7.

$$
V_{0}=\frac{G}{1-D} * V_{i}
$$

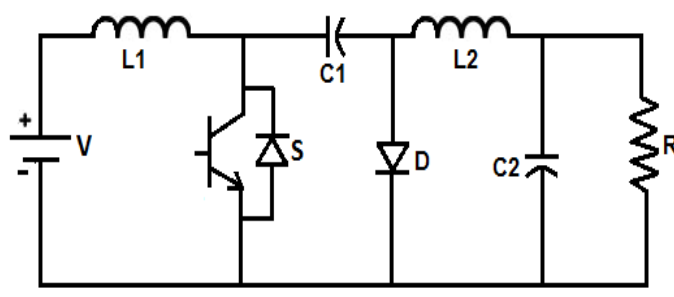

Figure 8. Circuit diagram of cuk converter

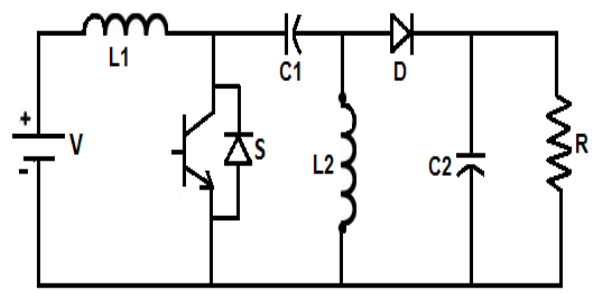

Figure 9. Circuit diagram of sepic converter

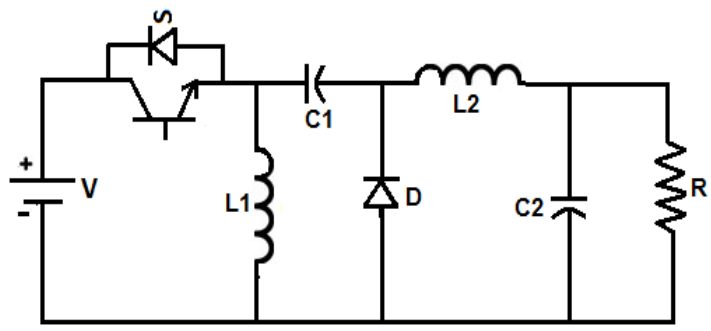

Figure 10. Circuit diagram of zeta converter

A cuk converter renovates a dc input voltage to dc output voltage with reversed polarity, which is shown in Figure 8. Compared to buck, boost and buck- boost converter, the cuk converter uses an extra inductor and capacitor to store the energy. When the power switch is ON condition, the current through inductor starts to increase linearly. And when the power switch is off condition, the diode carries the current; the energy is transferred from inductor to capacitor $\mathrm{C} 2$, result in decreasing the inductor current value. The voltage is,

$$
V_{0}=-\frac{G}{1-D} * V_{i}
$$


The single ended primary inductor converter is called as SEPIC converter, which generates the output dc voltage is greater than, less than or equal to applied input dc voltage. Its modified from buck- boost converter, which is shown in Figure $9 \&$ can be operated in continuous and discontinuous mode operation, when power switch is ON condition, the inductor L1 starts to charging and when brings to off condition the inductor L2 starts to discharging through capacitor C1, diode D and capacitor C2. From that the voltage can able increase, decrease or equal to applied voltage based on the duty ratio applied to the power switch.

Similarly zeta converter provides positive output voltage from the applied dc source, which may be greater or less than the applied input voltage. It consists of 2 inductors and 2 capacitors and a clamping diode, which is shown in Figure 10. When switch s is ON condition, inductor L1 is charging and when off condition its starts to discharging through $\mathrm{C} 1$ capacitor, L2 inductor and C2 capacitor, similar to sepic converter which can be operated in continuous and discontinuous mode operation. The output voltage equation is same boost converter, which is shown in Equation (6).

\section{SIMULATION RESULTS AND DISCUSSION}

The recital of the various dc-dc converter with PV system authenticated by using MATLAB simulation under different PV array operating situations. In Figure 11 \& Figure 12 shows simulink model for PV array and P\&O MPPT algorithm. The performance of the system is tested with various solar radiations from $400 \mathrm{~W} / \mathrm{m} 2$ to $800 \mathrm{~W} / \mathrm{m} 2$ and various temperatures $(0-38) \mathrm{C}$.

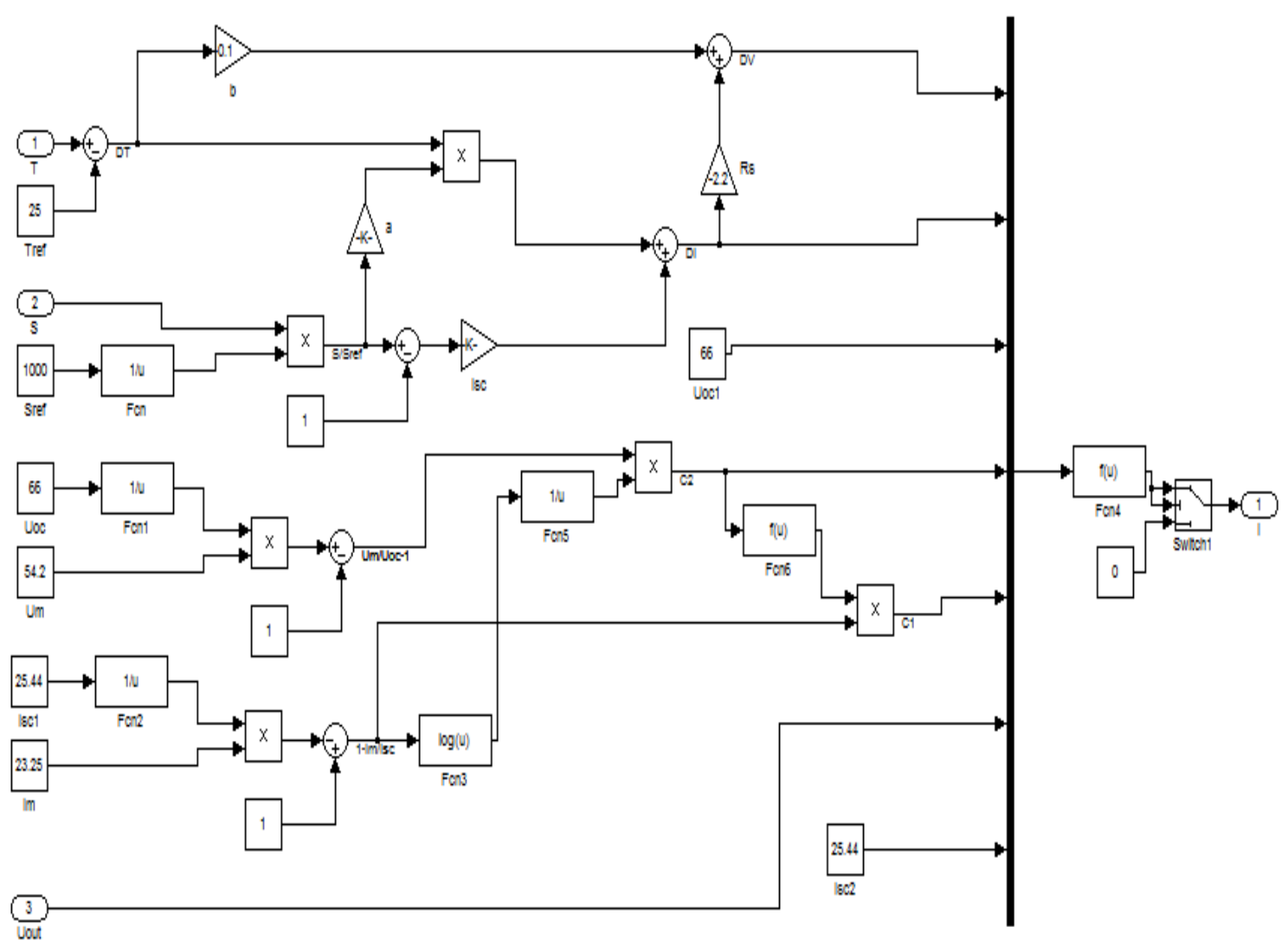

Figure 11. PV array model 


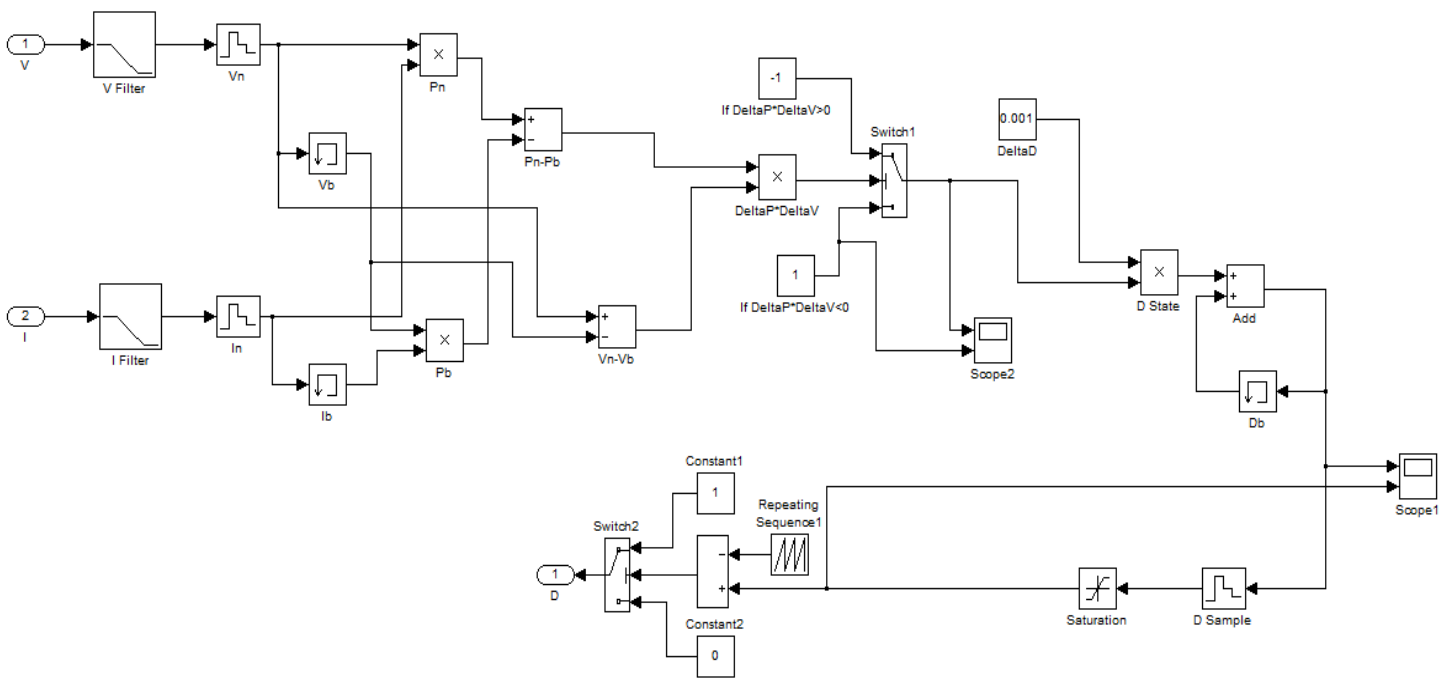

Figure 12. P\&O -MPPT algorithm

In Figure 13 shows duty ratio generation from MPPT algorithm, which various from 0 to 1. The various dc-dc converters are tested with PV system input dc voltage of $20 \mathrm{~V}$. The boost converter generates output $48 \mathrm{~V} \mathrm{dc}$, which is 2.4 times of applied input voltage, which is shown in Figure 14. In Figure 15 shows the buck dc voltage of $12 \mathrm{~V}$ with help buck converter. And negative voltage generated with help of buck-boost and cuk converter as $-32 \mathrm{~V}$ dc, which is shown in Figure 16 \& Figure 17 respectively.

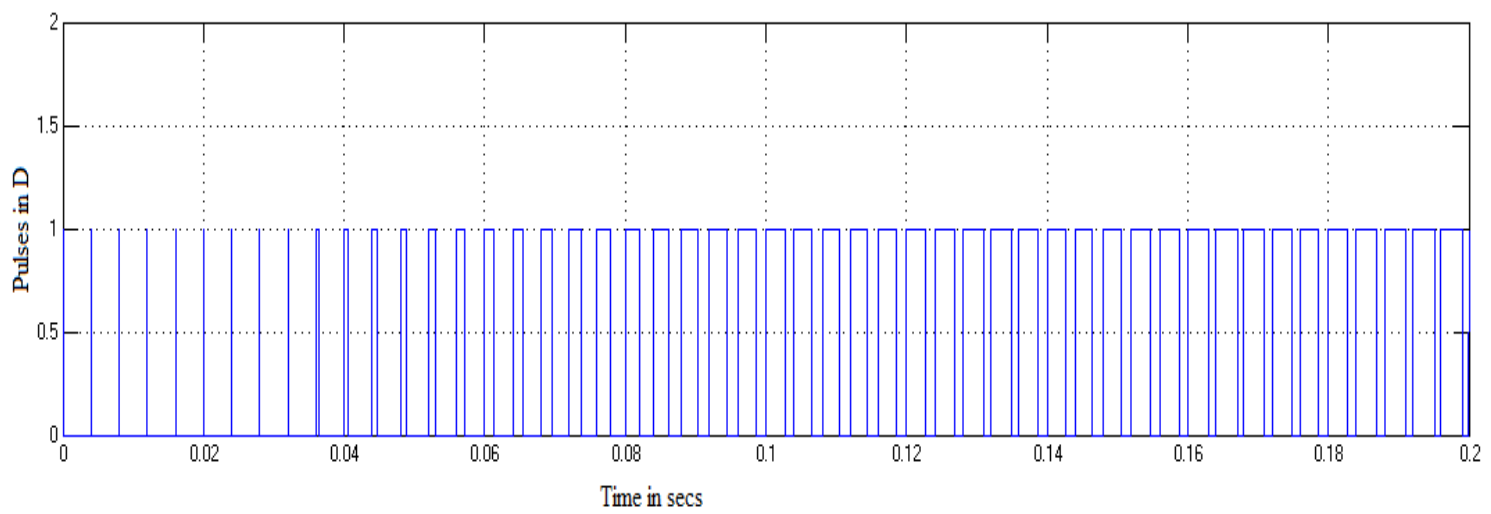

Figure 13. Pulses of MPPT algorithm

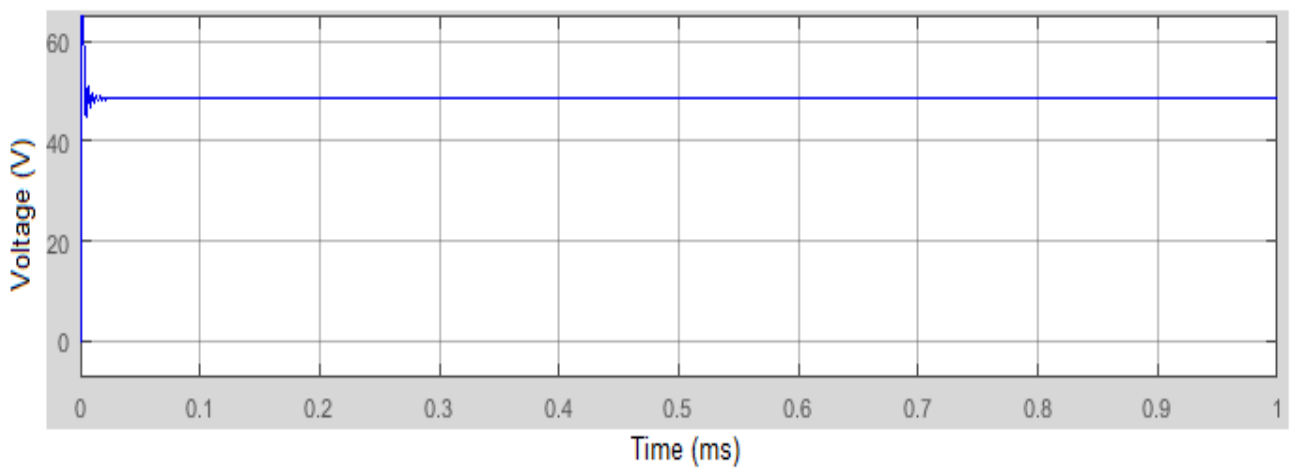

Figure 14. Output voltage of boost converter 


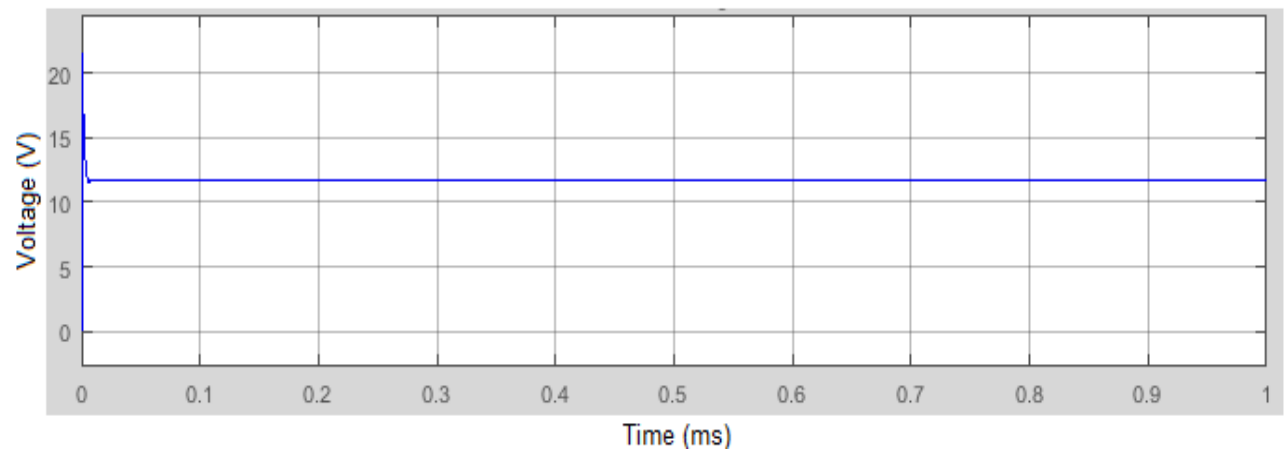

Figure 15. Output voltage of buck converter

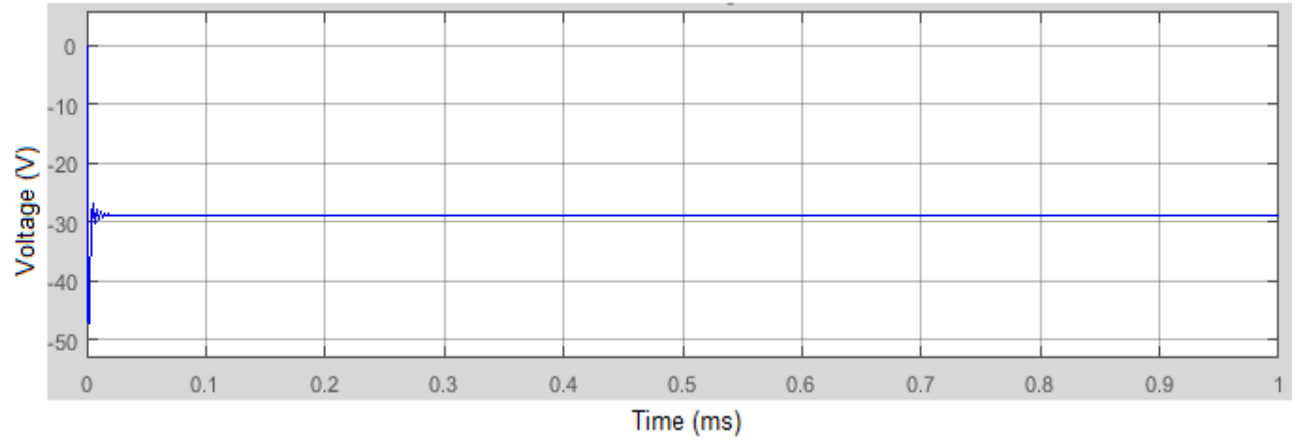

Figure 16. Output voltage of buck boost converter

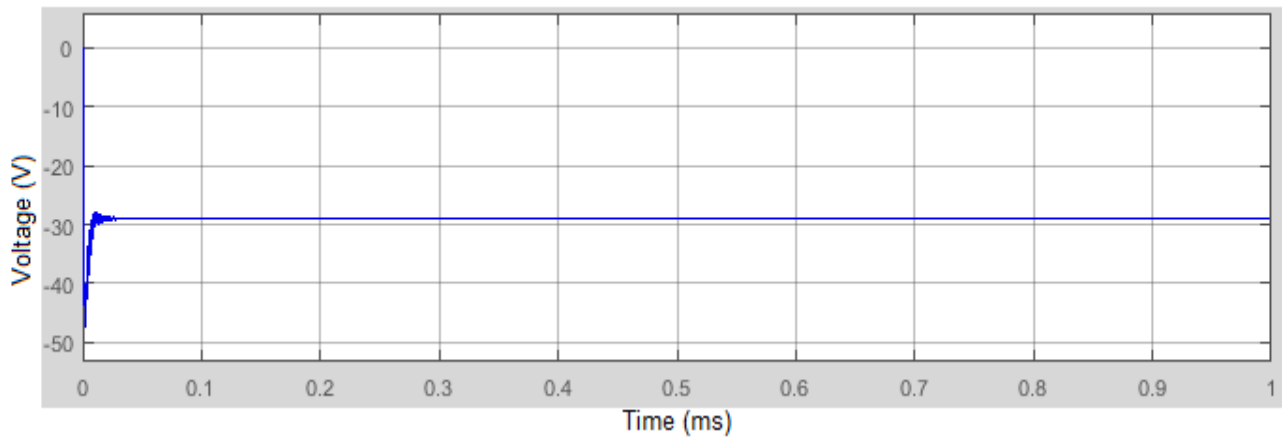

Figure 17. Output voltage of cuk converter

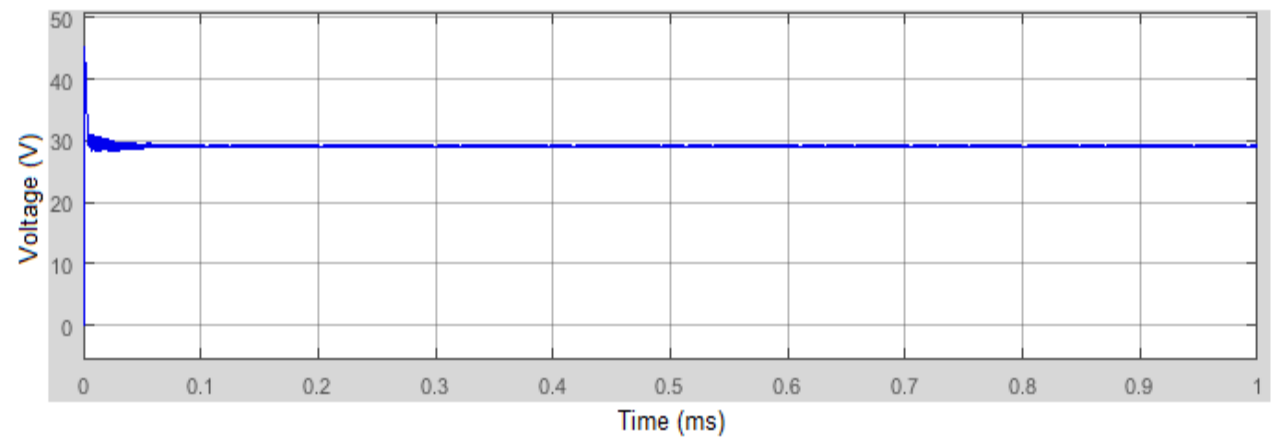

Figure 18. Output voltage of sepic converter 


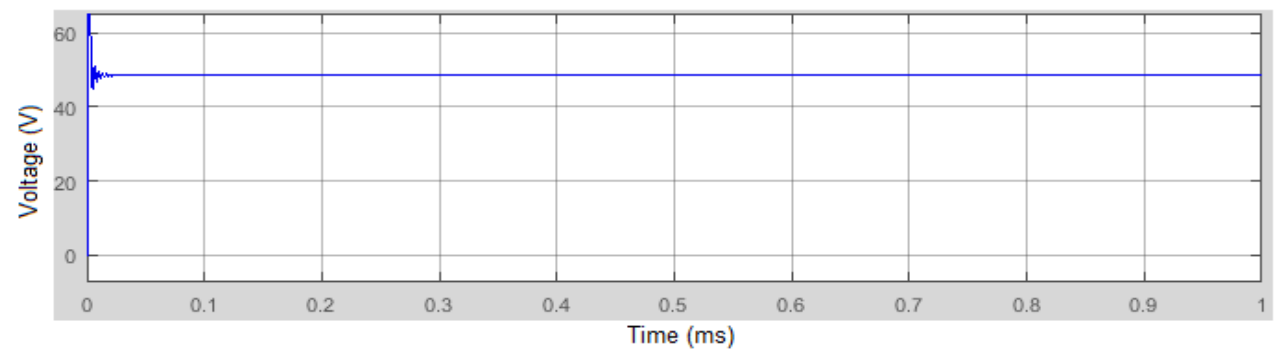

Figure 19. output voltage of zeta converter

Similarly in Figure 18 shows the output voltage of sepic converter with $30 \mathrm{~V}$ dc and zeta converter boost input voltage to $50 \mathrm{~V} \mathrm{dc}$, which is shown in Figure 19, which is better output voltage than the other conventional dc-dc converters.

\section{CONCLUSION}

Generally various dc-dc converter topologies are used for energy conversion system. In this paper, the renewable energy source is applied to various dc-dc converters are boost converter, buck converter, buck-boost converter, cuk converter, sepic and zeta converter are analysed. The output voltage of the converters are varied, which attains as increased, decreased or equal to applied voltage depends on the duty ratio produced from the $\mathrm{P} \& \mathrm{O}$ MPPT algorithm. The various dc-dc converters output voltage are verified using matlab/simulink.

\section{REFERENCES}

[1] Yang, W. Li, Y. Zhao, and X. He, "Design and analysis of a grid connected PV power system", IEEE Trans.Power Electron., vol. 25, no. 4, pp. 992-1000, Apr. 2010.

[2] J. Selvaraj and N. A. Rahim, "Multilevel inverter for grid-connected PV system employing digital PI controller",IEEE Trans. Ind. Electron., vol. 56, no. 1, pp. 149-158, Jan. 2009.

[3] L. S. Yang, T. J. Liang, H. C. Lee, and J. F. Chen, "Novel high step-up DC-DC converter with coupled-inductor and voltage doubler circuits", IEEE Trans. Ind. Electron., vol. 58, no. 9, pp. 4196- 4206, Sep. 2011.

[4] Q. Zhao and F. C. Lee, "High-efficiency, high step-up DC-DC converters," IEEE Trans. Power Electron., vol. 18, no. 1, pp. 65-73, Jan. 2003.

[5] R. Palanisamy, K. Vijayakumar "Maximum Boost Control for 7-level z-source cascaded h-bridge inverter ", International Journal of Power Electronics and Drive Systems(IJEPDS), vol 8, Issue 2, June 2017.

[6] W. Yu, H. Qian, and J. S. Lai, "Design of high-efficiency bidirectional dc-dc converter and high-precision efficiency measurement", IEEE Trans Power Electron., vol. 25, no. 3, pp. 650- 658, Mar. 2010.

[7] Y. R. J. Wai and R. Y. Duan, "High step-up converter with coupled inductor", IEEE Trans. Power Electron., vol. 20, no. 5, pp. 1025-1035, Sep. 2005.

[8] R. Palanisamy, K. Vijayakumar, Komari Nikhil, Madhumathi Iyer, Ramachandar Rao,"A Proposed SVM for 3level Transformer-less Dual Inverter Scheme for Grid Connected PV System" Indian Journal of Science and Technology, 2016 Nov, 9(42).

[9] Poh Chiang Loh, Feng Gao, FredeBlaabjerg, and Sokweilim. "Operational Analysis and Modulation Control of ThreeLevel Z-Source Inverters With Enhanced Output Waveform Quality". IEEE Transaction on Power Electronics, July 2010. Vol.24, No.7.

[10] S.C.Tan, Y.M.Lai, C.K. Tse, "Implementation of Pulse-Width- Modulation based Sliding Mode Controller for Boost converters," IEEE Power Electronics Letters, vol.3, No.4, Dec. 2006, pp.130-135.

[11] S.S.Muley, R.M.Nagarale, "Sliding Mode Control Of Boost converter," IJETAE ISSN:2250-2259, vol.3, Issue 9, Sept.2013.

[12] R. Palanisamy, A.U Mutawakkil, K. Vijayakumar "Hysteresis SVM for coupled inductor z source diode clamped 3level inverter based grid connected PV system”, International Journal of Power Electronics and Drive Systems(IJEPEDS), vol 7, Issue 4, Dec 2016.

[13] Q. Zhao and F. C. Lee, "High-efficiency, high step-up DC-DC converters," IEEE Trans. Power Electron., vol. 18, no. 1, pp. 65-73, Jan. 2003.

[14] W. Yu, H. Qian, and J. S. Lai, "Design of high-efficiency bidirectional dc-dc converter and high-precision efficiency measurement," IEEE Trans Power Electron., vol. 25, no. 3, pp. 650- 658, Mar. 2010.

[15] Y. R. J. Wai and R. Y. Duan, "High step-up converter with coupled inductor," IEEE Trans. Power Electron., vol. 20, no. 5, pp. 1025-1035, Sep. 2005.

[16] L.L.Buciarelli, B.L. Grossman, E.F.Lyon and N.E. Rasmussen, "The energy balance associated with the use of a MPPT in $100 \mathrm{~kW}$ peak power system", in IEE. 